J. Amer. Soc. Hort. ScI. 120(3):454-459. 1995.

\title{
Gas Exchange, Water Relations, and Dry Weight Partitioning during Root Initiation and Development of Poinsettia Cuttings
}

\author{
Sven E. Svenson \\ Fort Lauderdale Research and Education Center, University of Florida - IFAS, 3205 College Avenue, \\ Fort Lauderdale $F$ F 33314 \\ Fred T. Davies, Jr., and Sharon A. Duray \\ Department of Horticultural Sciences, Texas A\&MUniversity, College Station, TX 77843-2133
}

Additional index words. adventitious root formation, photosynthesis, Euphorbia pulcherrima, osmotic potential, relative water content

\begin{abstract}
Gas exchange, water relations, and dry weight partitioning of shoot tip cuttings of 'Eckespoint Lilo Red' ('Lilo') and 'Gutbier V-10 Amy Red' ('Amy') poinsettia (Euphorbia pulcherrima Wind. ex Klotzsch) were studied during the initiation and development of adventitious roots. Net photosynthesis $(A)$ and stomatal conductance (g) of cuttings were initially low and remained low until root primordia formation. Foliar relative water content (RWC) and osmotic potential $(\psi \pi)$ increased upon formation of root primordia. Following formation of root primordia (2 days before visible root emergence) and concurrent with increasing RWC and $\psi \pi$, g increased. As roots initially emerged, A and g increased rapidly and continued to increase with further root primordia development and subsequent emergence of adventitious roots. Cutting stem and leaf dry mass and leaf area increased during the first few days after sticking cuttings. During primordium development and initial root emergence, the highest percent increase in dry weight was accounted for by basal stem sections. AU cuttings of both cultivars rooted and had similar root numbers after 23 days, but 'Lilo' cuttings had $15 \%$ better rooting and $44 \%$ more roots than 'Amy' after 15 days. This research supports the hypothesis that formation and elongation of root primordia coincides with increased gas exchange in poinsettia cuttings, and that gas exchange can be used as a nondestructive indicator of adventitious root development.
\end{abstract}

The differing physiological responses of cuttings associated with the various developmental stages of adventitious root formation (ARF) are only vaguely understood (Andersen, 1986; Davis and Haissig, 1994; Haissig, 1988; Hartmann et al., 1990). The developmental stages of ARF include dedifferentiation, root initial formation, root primordia development, and elongation of primordia leading to root system growth and development. The first two stages are critical for successful rooting (Hartmann et al., 1990). Each stage is most likely associated with specific physiological responses. For example, two different phases of high and low auxin sensitivity have been described, and are associated with preprimordial (target) cells and the later stage of root primordium initiation (Gaspar and Hofinger, 1988).

A two-phase gas exchange response during ARF has generally been identified. Most cuttings undergo a steady decline in gas exchange after excision from the source plant, followed by increased gas exchange upon or following visible root emergence (Davis, 1988; Feldman et al., 1989; Smalley et al., 1991; von Schaesberg et al., 1993). Reduced gas exchange before root emergence might be caused by altered leaf water relations (Loach, 1988; Rein et al., 1991), altered hormone physiology (Hubick et al., 1988; Okoro and Grace, 1976; Smalley et al., 1991), or altered source-sink physiology (Feldmann et al., 1989; Humphries and

Received for publication 11 Aug. 1994. Accepted for publication 23 Nov. 1994 Texas Agricultural Experiment Station Journal Series No. TA-3 1774, Identification of trade products used does not imply endorsement nor criticism of similar products not used. The authors greatly appreciate the critical reviews of R.C. Beeson, Jr., T.D. Davis, J.R. Potter, W.M. Proebsting, D.K. Struve, Y.T. Wang, D.C. Wilkerson, and one anonymous reviewer. The authors thank Paul Ecke Poinsettias for supplying plant material, The cost of publishing this paper was defrayed in part by the payment of page charges. Under postal regulations, this paper therefore must be hereby marked advertisement solely to indicate this fact. ${ }^{1}$ To whom reprint requests should be addressed.
Thorne, 1964; Loach and Gay, 1979).

While previous studies have indicated changes in gas exchange associated with the exogenous morphological stages of ARF, none has reported gas exchange in response to endogenous anatomical development. Since ARF begins as an endogenous process (Hartmann et al., 1990), it is important to determine if gas exchange rates of leafy cuttings are influenced by the sequential anatomical stages of ARF.

To date, no studies have separated gas exchange rates and water relations responses among the discrete developmental stages of ARF in poinsettia. This study was conducted to determine if changes in gas exchange, water relations, and dry mass partitioning of poinsettia cuttings were linked to specific anatomical stages of ARF, and to determine if changes in gas exchange could be used as nondestructive indicators of the progress of ARF in poinsettia cuttings.

\section{Materials and Methods}

Leafy shoot tip cuttings (9 cm long) of 'Eckespoint Lilo Red' ('Lilo') and 'Gutbier V-10 Amy Red' ('Amy') poinsettia were excised from commercially grown plants and shipped overnight (Paul Ecke Poinsettias, Encinitas, Calif.). Upon arrival, cuttings were inserted (basal $4 \mathrm{~cm}$ ) into 6-cm-top diameter pots filled with $150 \mathrm{ml}$ of a 3 perlite $: 1$ peat (v/v) medium. The medium had been thoroughly rinsed with double-distilled (old) $\mathrm{H}_{2} \mathrm{O}$. No leaves were removed from cuttings before sticking, nor were rooting compounds used. Cuttings were rooted in a growth chamber: 24C; 380 $\pm 10 \mu \mathrm{CO}_{2} /$ liter; 16-h photoperiod; $180 \mu \mathrm{mol} \cdot \mathrm{m}^{-2} \cdot \mathrm{s}^{-1}(\mathrm{PPF})$, increased to $250 \mu \mathrm{mol} \cdot \mathrm{m}^{-2} \cdot \mathrm{s}^{-1} \mathrm{PPF}$ after 15 days, supplied by coolwhite fluorescent lamps and incandescent bulbs; 95\%-100\% relative humidity $(\mathrm{RH})$, reduced to $80 \%$ after 15 days.

For gas exchange measurements, 10 cuttings of each cultivar were removed from the growth chamber $(\approx 2 \mathrm{~h}$ after the start of the light 


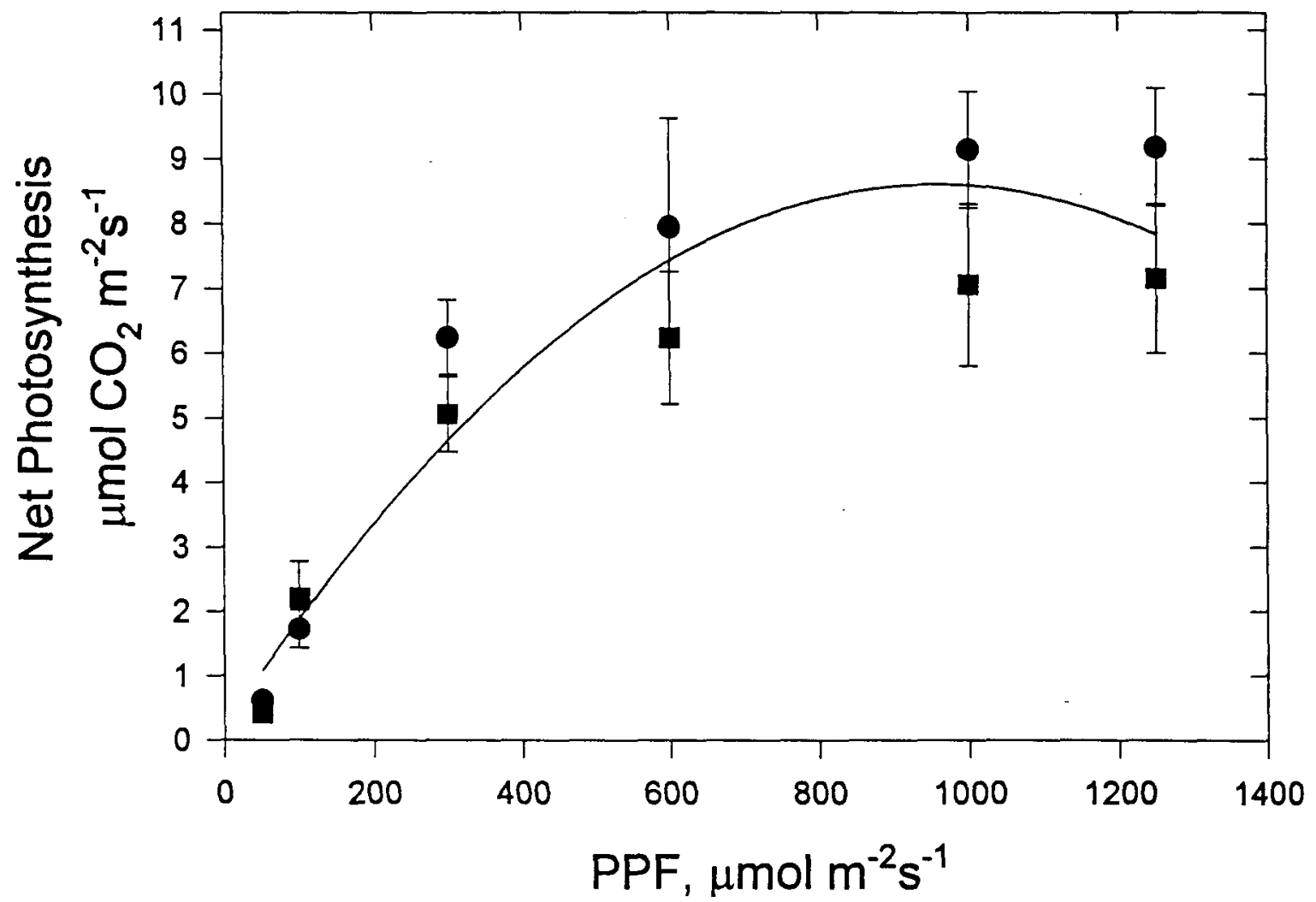

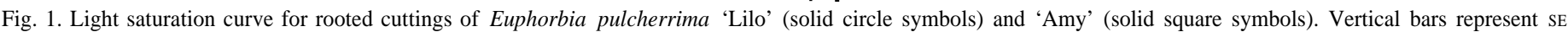
of means $(n=3)$. Regression of the pooled data: $\mathrm{A}=0.27 \pm 0.017(\mathrm{PPF})-\left[\left(1 \times 10^{-5}\right)(\mathrm{PPF})^{2}\right], r^{2}=0.96$.

cycle) and were acclimated for $30 \mathrm{~min}$ under a high-pressure sodium lamp (filtered through a $10-\mathrm{cm}$ water filter) under the following conditions: $22.1 \mathrm{C} ; 383 \pm 9 \mu \mathrm{m} \mathrm{CO}$ /liter; $423.7 \pm 5.5 \mu \mathrm{mol} \cdot \mathrm{m}^{-2} \cdot \mathrm{s}^{-1}$ PPF; and $57 \% \pm 5 \% \mathrm{RH}$. Gas exchange measurements were made at an ambient RH lower than the growth chamber. Light saturation of rooted cuttings was $\approx 375 \mu \mathrm{mol} \cdot \mathrm{m}^{-2} \cdot \mathrm{s}^{-1}$ (Fig. 1). Foliar gas exchange of net photosynthesis (A) and stomatal conductance ( $\mathrm{g}$ ) were measured on single, fully expanded leaves (first leaf from the apex having at least $6 \mathrm{~cm}^{2}$ leaf area) inserted into a 0.25 -liter leaf chamber of a portable photosynthesis system (LI-6200; LI-COR, Lincoln, Neb.). Measurements were made 1, 4, 6, 8, 10, 13, 15, and 23 days after cuttings were inserted into the propagation medium.

As gas exchange measurements were completed, the measured leaf was harvested for determination of relative water content (RWC) and osmotic potential (Y.). To determine RWC, the fresh weight of a $1-\mathrm{cm}^{2}$ leaf disc (without midvein tissue) was recorded. The disc was then floated on $\mathrm{dd}_{2} \mathrm{O}$ in a 9-cm petri dish for $2 \mathrm{~h}$ at $50 \mu \mathrm{mol} \cdot \mathrm{m}^{-2} \cdot \mathrm{s}^{-1} \mathrm{PPF}$ and $22.2 \pm 1.0 \mathrm{C}$, reweighed after removal of excess surface moisture, and weighed after drying for $30 \mathrm{~h}$ at $80 \mathrm{C}$. A standard RWC calculation was used (Turner, 1981). A second disc from the same leaf (enclosed in an airtight vial) was frozen (liquid $\mathrm{N}$ ) and then thawed in a humid chamber before $\Psi_{\pi}$ was determined using a C-52 chamber in conjunction with a HR33T dewpoint hygrometer (Wescor, Logan, Utah), according to Turner (1981).

To determine growth and rooting responses, 10 cuttings of each cultivar were harvested during seven sampling periods: 1,4, 6, 8, 13,15 , and 23 days after cuttings were stuck. The number of leaves, leaf area, leaf dry weight, total cutting dry weight, dry weight of apical and basal portions (basal $1 \mathrm{~cm}$ which included roots when present) of cuttings and percentage rooting and number of visible roots (> $1 \mathrm{~mm}$ ) were recorded. A leaf area meter (LI-COR 3000; LICOR) was used to measure leaf area. At day 10, cuttings were sampled for gas exchange, but no water relations or cutting dry weight data were taken.

During the eight sampling periods (which included day 10), the basal $1 \mathrm{~cm}$ of stems of additional cuttings were fixed in formalinacetic acid-ethanol in vacuo and embedded in Paraplast-plus after serial dehydration in ethanol-tertiary butyl alcohol and serial cross-sections were cut at $11 \mu \mathrm{m}$, stained with safranin and fast green, and microscopically analyzed for development of root primordia (Davies et al., 1982).

The experiment was a completely randomized design with 10 replications $(n=10)$ per treatment. Data were analyzed using analysis of variance, orthogonal contrasts, and regression analysis (SAS Institute, Cary, N.C.).

\section{Results}

Before formation of root primordia, A and $\mathrm{g}$ were low (Table 1). On day 13 when root primordia were first microscopically observed (Fig. 2), g was more than double the average of previous days for both cultivars. Cutting A also increased slightly on day 13 . Two days later, as primordia elongated and roots visibly emerged (day 15), A and g continued to increase. There was a significant interaction between cultivars for A and g when days 15 and 23 were compared to day 13 , but generally gas exchange responses were similar for both cultivars.

Root primordia were microscopically observed by day 13 , and visible roots emerged on day 15 (Table 1, Fig. 2). 'Lilo' had a greater percentage of rooted cuttings and more roots per cutting than 'Amy' on day 15. However, by day 23, all cuttings had rooted, and no cultivar differences in number of roots existed (Table 1).

Leaf RWC of 'Lilo' and 'Amy' declined through day 8 and increased dramatically with the development of root primordia on day 13 (Table 2). Osmotic potential $\left(\psi_{\pi}\right)$ was higher on day 13 (root 
Table 1, Net $\mathrm{CO}_{2}$ exchange rate (A), stomatal conductance (g), and rooting of 'Lilo' and 'Amy' poinsettia cuttings by day. (Means and standard errors for root number, $\mathrm{n}=7$, for all other means, $\mathrm{n}=10$ ).

\begin{tabular}{|c|c|c|c|c|c|c|}
\hline Cultivar & Day & $\frac{\mathrm{A}}{\left(\mu \mathrm{mol} \mathrm{CO} / \mathrm{m}^{2} \text { per sec }\right)}$ & $\underset{\left(\mathrm{mmol} \mathrm{H}_{2} \mathrm{O} / \mathrm{m}^{2} \text { per sec }\right)}{\stackrel{g}{ }}$ & $\begin{array}{l}\text { No. } \\
\text { of } \\
\text { roots }\end{array}$ & $\begin{array}{c}\% \\
\text { Rooted }^{\prime}\end{array}$ & $\begin{array}{c}\text { Root } \\
\text { primordia } \\
\text { present }\end{array}$ \\
\hline \multirow[t]{8}{*}{ Lilo } & 1 & $0.9 \pm 0.2$ & $6.4 \pm 2.0$ & 0 & 0 & No \\
\hline & 4 & $1.3 \pm 0.3$ & $9.8 \pm 2.5$ & 0 & 0 & No \\
\hline & 6 & $1.3 \pm 0.2$ & $15.0 \pm 2.9$ & 0 & 0 & No \\
\hline & 8 & $1.2 \pm 0.2$ & $9.3 \pm 2.7$ & 0 & 0 & No \\
\hline & 10 & $1.5 \pm 0.3$ & $10.0 \pm 2.5$ & 0 & 0 & No \\
\hline & 13 & $2.2 \pm 0.4$ & $37.0 \pm 12$ & 0 & 0 & Yes \\
\hline & 15 & $7.4 \pm 1.0$ & $56.0 \pm 8.7$ & $26 \pm 3$ & 84 & Yes \\
\hline & 23 & $9.8 \pm 0.6$ & $70.0 \pm 12$ & $36 \pm 3$ & 100 & Yes \\
\hline \multirow[t]{8}{*}{ Amy } & 1 & $1.0 \pm 0.2$ & $5.9 \pm 2.9$ & 0 & 0 & No \\
\hline & 4 & $1.1 \pm 0.2$ & $7.7 \pm 2.9$ & 0 & 0 & No \\
\hline & 6 & $1.1 \pm 0.2$ & $9.1 \pm 2.7$ & 0 & 0 & No \\
\hline & 8 & $1.3 \pm 0.3$ & $13.0 \pm 2.7$ & 0 & 0 & No \\
\hline & 10 & $1.3 \pm 0.3$ & $10.0 \pm 2.3$ & 0 & 0 & No \\
\hline & 13 & $2.0 \pm 0.6$ & $23.0 \pm 7.0$ & 0 & 0 & Yes \\
\hline & 15 & $9.1 \pm 0.7$ & $80.0 \pm 13$ & $18 \pm 3$ & 71 & Yes \\
\hline & 23 & $7.6 \pm 0.8$ & $52.0 \pm 12$ & $36 \pm 7$ & 100 & Yes \\
\hline \multicolumn{7}{|c|}{ Contrast $^{\mathrm{y}}$} \\
\hline \multicolumn{2}{|c|}{ Day 8 vs. day 1-6 (C1) } & NS & NS & NS & NS & \\
\hline \multicolumn{2}{|c|}{ Day 10 vs. day $1-8(\mathrm{C} 2)$} & NS & NS & NS & NS & \\
\hline \multicolumn{2}{|c|}{ Day 13 vs. day $1-10$ (C3) } & 0.01 & 0.001 & NS & NS & \\
\hline \multicolumn{2}{|c|}{ Day 13 vs. day $15-23$ (C4) } & 0.001 & 0.001 & 0.001 & 0.001 & \\
\hline \multicolumn{2}{|c|}{ Lilo vs. Amy (CULT) } & NS & NS & 0.001 & 0.001 & \\
\hline \multicolumn{2}{|c|}{$\mathrm{C} 1 \times \mathrm{CULT}$} & NS & NS & NS & NS & \\
\hline \multicolumn{2}{|c|}{$\mathrm{C} 2 \times \mathrm{CULT}$} & NS & NS & NS & NS & \\
\hline \multicolumn{2}{|c|}{$\mathrm{C} 3 \times \mathrm{CULT}$} & NS & NS & NS & NS & \\
\hline \multicolumn{2}{|c|}{$\mathrm{C} 4 \times \mathrm{CULT}$} & 0.001 & 0.01 & 0.001 & 0.001 & \\
\hline
\end{tabular}

primordia formation) compared to days 1 through 8 (Table 2).

Increases in leaf area, leaf dry weight, and total cutting dry weight occurred the first few days after cuttings were stuck (Table 2). During primordium formation and first visible root emergence (days 13 to 15), both cultivars averaged a 53\% increase in basal stem dry weight, which increased to $230 \%$ on day 23 when all cuttings had rooted. Growth of the two cultivars increased in other parameters measured from days 15 to 23 , but at a rate lower than basal stem dry weight: leaf area (25\%), leaf dry weight (32\%), apical stem dry weight (20\%), and total cutting dry weight (47\%).

\section{Discussion}

The strength of this study was that physiological measurements were keyed to root primordia development and elongation, not simply to the presence or absence of roots. In previous studies of leafy cuttings (including woody plants), photosynthesis slowly declined for a few days after excision from the source plant, and remained low until roots emerged (Davis, 1988; Davis and Potter, 1981, 1987; Feldman et al., 1989; Smalley et al., 1991). The slow initial decline in A was not recorded in this study on poinsettia, nor for unrooted cuttings of Pelargonium $\times$ hortorum that had been shipped unrooted (Arteca et al., 1985). An initial decline in A may have been recorded for poinsettia if measurement of gas exchange was started immediately following excision from the source plant, rather than after the cuttings had been shipped overnight air express before sticking (which is common practice in the commercial production of poinsettia).

$\mathrm{A}$ and $\mathrm{g}$ of unrooted cuttings remained low and were unresponsive to increasing PPF. On day 8, A and g of unrooted cuttings did not increase when PPF was increased from 50 to $425 \mu \mathrm{mol} \cdot \mathrm{m}^{-2} \cdot \mathrm{s}^{-1}$ (data not shown), whereas A and $\mathrm{g}$ of rooted cuttings (day 24) increased with increasing PPF up to $\approx 375 \mu \mathrm{mol} \cdot \mathrm{m}^{-2} \cdot \mathrm{s}^{-1}$ (Fig. 1). Differing light saturation levels for rooted and unrooted cuttings has been previously reported (Machida et al., 1977; von Schaesberg et al., 1993).

Increasing $\mathrm{g}$ was associated with primordia initiation and development (day 13), and A and g continued to increase with primordia elongation and the first day of visible root emergence (day 15). During primordium elongation and root emergence (days 13 to 15), all cutting dry weight accumulated in the basal stem and emerging roots. Photosynthesis reportedly increased with or following visible root emergence in other species (Davis, 1988; Feldmann et al., 1989; Okoro and Grace, 1976; Smalley et al., 199 1). Von Schaesberg et al. (1993) reported increased A for cuttings of one of two Mangifera rootstock following exogenous calli formation and before visible root emergence, but they did not study anatomical development. In contrast to increased A and g before visible root formation of poinsettia or Mangifera cuttings, A of Simmondsia cuttings (Feldman et al., 1989), and g of Cornus cuttings (Gay and Loach, 1977) remained low until a measurable root length developed. In previous studies, A returned to peak levels most rapidly in cuttings that rooted quickly (Machida et al., 

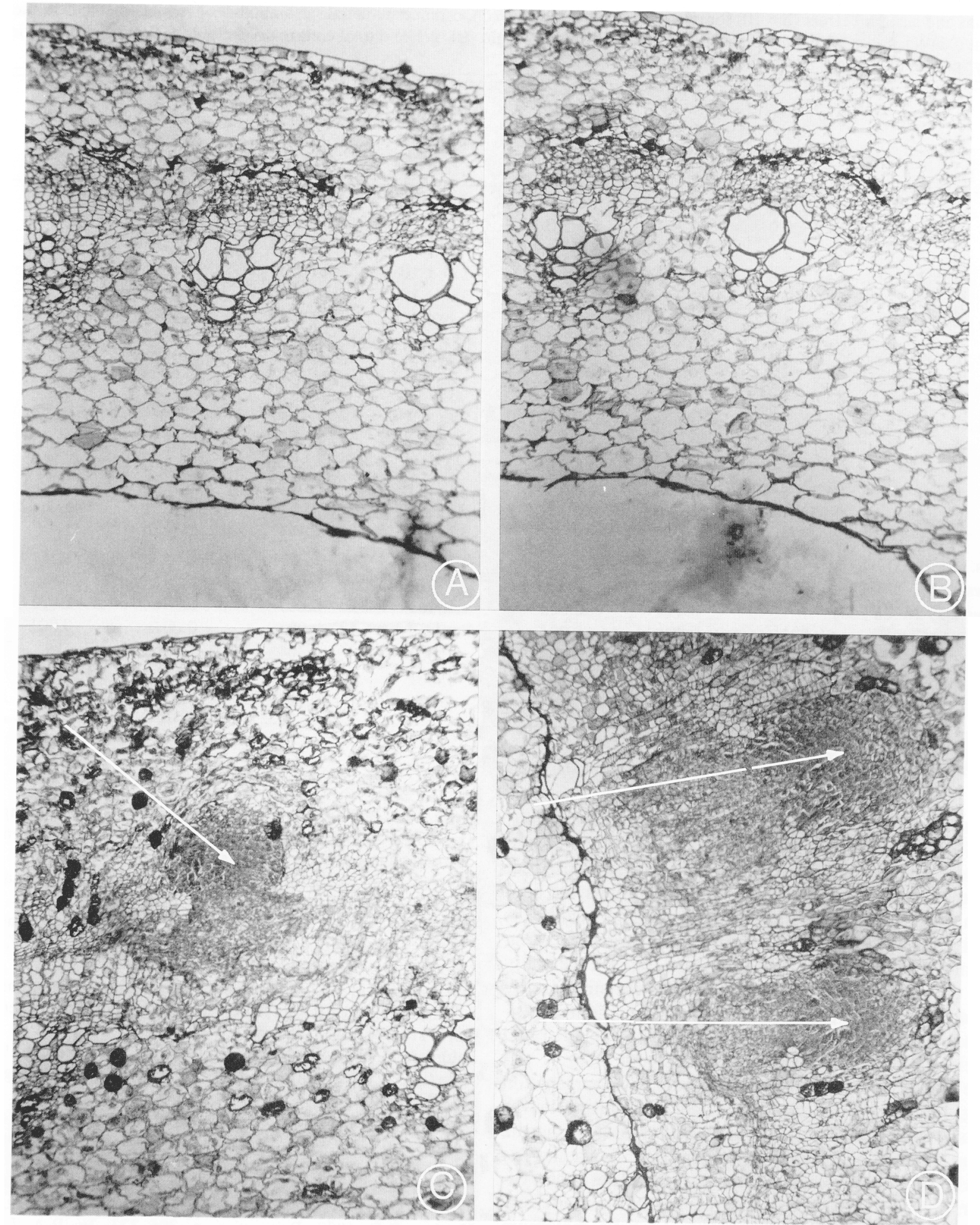

Fig. 2. Cross-sections of Euphorbia pulcherrima stem cutting bases: (A) 10 days after sticking cuttings for 'Lilo,' 128x; (B) 10 days after sticking cuttings for 'Amy,' 128x; (C) 13 days after sticking cuttings for 'Lilo,' 400x; (D) 13 days after sticking cuttings for 'Amy,' 400x. Arrows indicate root primordia.

1977; von Schaesberg et al., 1993; Smalley et al., 1991). Our data indicates that leaf gas exchange continues before root emergence, but at a reduced rate, and increases rapidly upon root emergence and elongation.

The low rates of gas exchange before root primordia formation are likely due to water stress and stomatal closure (Davis, 1988; Loach, 1988). Concurrent reductions in g, RWC and reduced A before root primordia formation, and then recovery of $\mathrm{g}$ and RWC and subsequent increase in A upon root emergence supports the hypothesis that water stress limits $\mathrm{A}$ in unrooted cuttings. The lower RWC in 'Lilo' compared to 'Amy' cuttings (day 8) may have been caused by larger leaf area increasing water stress.

It cannot be determined from the poinsettia response whether it is a water relations, hormonal, or source-sink event that occurs first in association with increasing $\mathrm{A}$ and $\mathrm{g}$ upon primordia formation. However, the gas exchange and dry weight partitioning of poinsettia cuttings are linked to the developmental stages of ARF.

Light quantities of $285-475 \mu \mathrm{mol} \cdot \mathrm{m}^{-2} \cdot \mathrm{s}^{-1} \mathrm{PPF}$ (Hartley, 1992) 
Table 2. Means and standard errors $(n=10)$ for relative water content $\left(\right.$ RWC), osmotic potential $\left(\psi_{\pi}\right)$, number of leaves, total leaf surface area, leaf dry weight (LDW), upper stem dry weight (SDW), basal stem dry weight (BDW), and total cutting dry weight (TCDW) during rooting of 'Lilo' and 'Amy' poinsettia cuttings by day.

\begin{tabular}{|c|c|c|c|c|c|c|c|c|c|}
\hline Cultivar & Day & $\begin{array}{c}\text { RWC } \\
(\%)\end{array}$ & $\begin{array}{c}\Psi_{\pi} \\
(\mathrm{MPa})\end{array}$ & $\begin{array}{c}\text { No. } \\
\text { of } \\
\text { leaves }\end{array}$ & $\begin{array}{l}\text { Leaf } \\
\text { area } \\
\left(\mathrm{cm}^{2}\right)\end{array}$ & $\begin{array}{l}\text { Leaf } \\
\text { dry wt } \\
(\mathrm{mg})\end{array}$ & $\begin{array}{c}\text { Apical } \\
\text { stem } \\
\text { dry wt } \\
(\mathrm{mg})\end{array}$ & $\begin{array}{c}\text { Basal } \\
\text { stem } \\
\text { dry wt } \\
(\mathrm{mg})\end{array}$ & $\begin{array}{c}\text { Total } \\
\text { cutting } \\
\text { dry wt } \\
\text { (mg) }\end{array}$ \\
\hline \multirow[t]{7}{*}{ Lilo } & 1 & $90.9 \pm 1.6$ & $-1.8 \pm 0.2$ & $5.8 \pm 0.2$ & $144 \pm 8$ & $433 \pm 3$ & $40 \pm 3$ & $30 \pm 4$ & $503 \pm 43$ \\
\hline & 4 & $86.9 \pm 0.9$ & $-1.3 \pm 0.4$ & $6.4 \pm 0.3$ & $174 \pm 12$ & $564 \pm 43$ & $60 \pm 3$ & $40 \pm 4$ & $664 \pm 48$ \\
\hline & 6 & $80.1 \pm 2.7$ & $-1.3 \pm 0.1$ & $6.6 \pm 0.2$ & $160 \pm 9$ & $507 \pm 33$ & $57 \pm 3$ & $39 \pm 2$ & $603 \pm 46$ \\
\hline & 8 & $82.7 \pm 2.0$ & $-1.0 \pm 0.1$ & $7.1 \pm 0.1$ & $171 \pm 10$ & $567 \pm 39$ & $74 \pm 4$ & $54 \pm 5$ & $695 \pm 66$ \\
\hline & 13 & $88.8 \pm 0.6$ & $-0.9 \pm 0.1$ & $7.1 \pm 0.3$ & $164 \pm 10$ & $605 \pm 41$ & $131 \pm 9$ & $59 \pm 7$ & $795 \pm 76$ \\
\hline & 15 & $88.9 \pm 1.5$ & $-1.1 \pm 0.1$ & $7.2 \pm 0.3$ & $149 \pm 10$ & $571 \pm 45$ & $147 \pm 15$ & $100 \pm 17$ & $818 \pm 81$ \\
\hline & 23 & $91.8 \pm 0.5$ & $-1.2 \pm 0.1$ & $8.2 \pm 0.4$ & $202 \pm 7$ & $753 \pm 31$ & $141 \pm 12$ & $209 \pm 17$ & $1103 \pm 54$ \\
\hline \multirow[t]{7}{*}{ Amy } & 1 & $88.6 \pm 1.1$ & $-1.6 \pm 0.2$ & $5.0 \pm 0.3$ & $89 \pm 6$ & $256 \pm 26$ & $67 \pm 3$ & $39 \pm 4$ & $362 \pm 45$ \\
\hline & 4 & $85.6 \pm 1.4$ & $-1.4 \pm 0.3$ & $4.8 \pm 0.3$ & $109 \pm 9$ & $351 \pm 40$ & $79 \pm 4$ & $47 \pm 4$ & $477 \pm 69$ \\
\hline & 6 & $85.7 \pm 0.9$ & $-1.2 \pm 0.2$ & $5.3 \pm 0.3$ & $99 \pm 9$ & $313 \pm 39$ & $81 \pm 3$ & $41 \pm 3$ & $435 \pm 59$ \\
\hline & 8 & $86.1 \pm 0.8$ & $-1.5 \pm 0.2$ & $5.6 \pm 0.3$ & $102 \pm 8$ & $341 \pm 40$ & $101 \pm 8$ & $59 \pm 6$ & $501 \pm 67$ \\
\hline & 13 & $90.3 \pm 0.9$ & $-0.9 \pm 0.1$ & $5.8 \pm 0.2$ & $118 \pm 6$ & $436 \pm 30$ & $134 \pm 8$ & $62 \pm 5$ & $632 \pm 29$ \\
\hline & 15 & $86.2 \pm 1.5$ & $-1.2 \pm 0.1$ & $6.4 \pm 0.3$ & $119 \pm 13$ & $437 \pm 63$ & $131 \pm 16$ & $85 \pm 15$ & $653 \pm 105$ \\
\hline & 23 & $90.7 \pm 0.9$ & $-1.2 \pm 0.1$ & $7.4 \pm 0.4$ & $151 \pm 13$ & $614 \pm 70$ & $177 \pm 16$ & $190 \pm 42$ & $981 \pm 167$ \\
\hline \multicolumn{10}{|l|}{ Contrast $^{\mathrm{z}}$} \\
\hline \multicolumn{2}{|c|}{ Day 8 vs. day $1-6(\mathrm{C} 1)$} & NS & NS & NS & NS & NS & NS & NS & 0.03 \\
\hline \multicolumn{2}{|c|}{ Day 13 vs. day $1-8(\mathrm{C} 2)$} & 0.001 & 0.004 & 0.02 & NS & 0.01 & 0.04 & NS & NS \\
\hline \multirow{2}{*}{\multicolumn{2}{|c|}{ Day 13 vs. day $15-23$ (C3) }} & ) NS & 0.01 & 0.003 & 0.001 & 0.001 & 0.001 & 0.001 & 0.003 \\
\hline & & 0.001 & 0.001 & 0.001 & NS & 0.001 & 0.001 & 0.001 & 0.001 \\
\hline \multicolumn{2}{|c|}{$\mathrm{C} 1 \times \mathrm{CULT}$} & 0.02 & NS & 0.001 & 0.001 & 0.001 & NS & NS & NS \\
\hline \multicolumn{2}{|c|}{$\mathrm{C} 2 \times \mathrm{CULT}$} & 0.01 & 0.001 & 0.001 & 0.001 & 0.001 & NS & NS & 0.04 \\
\hline \multicolumn{2}{|c|}{$\mathrm{C} 3 \times \mathrm{CULT}$} & 0.03 & NS & NS & 0.02 & 0.001 & 0.01 & 0.001 & 0.001 \\
\hline
\end{tabular}

${ }^{2}$ Probability of a significance $\mathrm{F}$ value.

Ns Nonsignificant $(P>0.05)$.

have been suggested to optimize rooting of poinsettia cuttings. Increasing PPF from 50 to $425 \mu \mathrm{mol} \cdot \mathrm{m}^{-2} \cdot \mathrm{s}^{-1}$ did not increase A or gin unrooted poinsettia cuttings. If higher light is beneficial to root initiation and primordia formation in poinsettia cuttings, the benefit is not a result of increased gas exchange. Light quantity is reported to influence the activity of auxins and synergistic rooting co-factors in cuttings (Gaspar and Hofinger, 1988). Potentially lower light quantities could be used to hasten root initiation by reducing water stress (Loach, 1988), with increasing light quantities used just before root primordia emergence to support rapid primordia elongation and root system development.

With the close association of root primordia development and increased" gas exchange, monitoring A and g of cutting leaves could be used as a nondestructive indicator of root primordia development and imminent visible root emergence. To a poinsettia producer, when increased stomatal conductance and net photosynthesis occurs, it should be a cue that it is time to raise light intensity of the propagation beds, so that cuttings can have maximum photosynthesis and more rapid root development.

\section{Literature Cited}

Andersen, A.S. 1986. Environmental influences on adventitious rooting in cuttings of non-woody species, p. 223-253. In: M.B. Jackson (ed.). New root formation in plants and cuttings. Martinus Nijhoff, Boston.

Arteca, R.N., D.-S. Tsai, and C. Schlagnhaufer. 1985. Abscisic acid effects on photosynthesis and transpiration in geranium cuttings. HortScience 20:370-372.

Davies, F.T., Jr., J.E. Lazarte, and J.N. Joiner. 1982. Initiation and development of roots in juvenile and mature leaf bud cuttings of Ficus pumila. Amer. J. Bet. 69:804811.
Davis, T.D. 1988. Photosynthesis during adventitious rooting, p. 79-87. In: T.D. Davis, B.E. Haissig, and N. Sankhla (eds.). Adventitious root formation in cuttings. Dioscorides Press, Portland, Ore.

Davis, T.D. and B.E. Haissig (eds.). 1994. The biology of adventitious root formation. Plenum Press, New York.

Davis, T.D. and J.R. Potter. 1981. Current photosynthate as a limiting factor in adventitious root formation on leafy pea cuttings. J. Amer. Soc. Hort. Sci. 106:278-282.

Davis, T.D. and J.R. Potter. 1987. Physiological response of rhododendron cuttings to different light levels during rooting. J. Amer. Soc. Hort. Sci. 112:256-259.

Feldman, W. R., D.A. Palzkill, A.K. Dobrenz, and L. Hogan. 1989. Carbon dioxide exchange during mist propagation of jojoba cuttings. Agron. J. 81:233-236.

Gaspar, T. and M. Hotinger. 1988. Auxin metabolism during adventitious rooting, p. 117-131. In: T.D. Davis, B.E. Haissig, and N. Sankhla (eds.). Adventitious root formation in cuttings. Dioscorides Press, Portland, Ore. Gay, A.P. and K Loach. 1977. Leaf conductance changes on leafy cuttings of Cornus and Rhododendron during propagation. J. Hot Sci. 52:509-516.

Hartley, D.E. 1992. Poinsettias, p. 305-331. In: R.A. Larson (ed.). Introduction to floriculture. 2nd ed. Academic Press, New York.

Hartmann, H.T., D.E. Kester, and F.T. Davies, Jr. 1990. Plant propagation principles and practices. 5th ed. Prentice Hall, Englewood Cliffs, N.J. Haissig, B.E. 1988. Future directions in adventitious rooting research, p. 303-3 10. In: T.D. Davis, B.E. Haissig, and N. Sankhla (eds.). Adventitious root formation in cuttings. Dioscorides Press, Portland, Ore.

Hubick, K.T., J.S. Taylor, and D.M. Reid. 1988. The effect of drought on levels of abscisic acid, cytokinins, gibberellins and ethylene in aeroponicallygrown sunflower plants. Plant Growth Regulat.4:139-151.

Humphries, E.C. and G.N. Thorne. 1964. The effect of root formation on photosynthesis of detached leaves. Ann. Bet. 28:391400.

Loach, K. 1988. Water relations and adventitious rooting, p. 104-116. In: 
T.D Davis, B.E. Haissig, and N. Sankhla (eds.).Adventitious root formation in cuttings. Dioscondes Press, Portland, Ore.

Loach, K. and A.P. Gay. 1979., The light requirement for propagating hardy ornamental species from leafy cuttings. Scientia Horti. 10:217-230.

Machida, H., A. Ooishi, T. Hosoi, H. Komatsu, and F. Kamota. 1977. Studies on photosynthesis of cuttings during propagation. I. Changes in the rate of apparent photosynthesis in the cuttings of several plants after planting. J. Jpn. Soc. Hort. Sci. 46:274-282.

Okoro, O.O. and J. Grace, 1976. The physiology of rooting Populus cuttings. I. Carbohydrates and photosynthesis. Physiol. Plant. 36: 133-138.

Rein, W. H., R.D. Wright, and J.R. Seiler. 1991. Propagation medium moisture level influences adventitious rooting of woody stem cuttings. J. Amer. Soc. Hort. Sci. 116:632-636.

Smalley, T.J., M.A. Dirr, A.M. Armitage, B.W. Wood, R.O. Teskey, and R.F. Severson. 1991. Photosynthesis and leaf water, carbohydrate, and hormone status during rooting of stem cuttings of Acer rubrum. J. Amer. Soc. Hort. Sci. 116: 1052-1057.

Turner, N.C. 1981. Techniques and experimental approaches for the measurement of plant water status. Plant and Soil 58:339-366.

von Schaesberg, N., G. Ebert, and P. Ludders. 1993. Leaf gas exchange of mango (Mangifera indica L.) cuttings during adventitious root formation. Angew. Bot. 67:14-16. 